RESEARCH PAPER

\title{
Isolation, partial purification and characterization of peroxidase enzyme from orange seed
}

\author{
SHAILJA* AND SAIMA H. KHAN \\ Department of Chemistry, Sam Higginbottom Institute of Agriculture, Technology and Sciences, \\ ALLAHABAD (U.P.) INDIA
}

\begin{abstract}
The aim of this research was the isolation, partial purification and characterization of peroxidase from orange seed. The guaiacol is used as substrate in the detection of enzymatic activity of peroxidase. The optimization of extraction process was done by controlling the type and concentration of buffer, $\mathrm{pH}$ of the buffer used. The phosphate buffer with $0.1 \mathrm{M}$ and $\mathrm{pH} 6.5$ was found to be the best buffer for extraction of peroxidase. Peroxidase activity in crude extract of orange seeds was measured by recording a spectrophotometric value. Partial purification of crude enzyme extract was done by ammonium sulphate precipitation. It was observed that after partial purification, the enzyme activity was increased as compared to crude enzyme extract. It is more evident that peroxidase is the most heat stable enzyme, therefore, it is concluded that it may be potentially useful for industrial purposes. Characterization results demonstrated that, the optimal $\mathrm{pH}$ for activity and stability was 7 and 7-7.5, respectively, the optimal temperature for activity and stability was 45 and 30-40 ${ }^{\circ} \mathrm{C}$, respectively.
\end{abstract}

Key Words : Orange seeds, Extraction, Peroxidase, Purification, Characterization

View point paper : Shailja and Khan, Saima H. (2015). Isolation, partial purification and characterization of peroxidase enzyme from orange seed. Asian Sci., 10 (1\&2): 18-21.

\footnotetext{
* Author for correspondence

Shailja, Department of Chemistry, Sam Higginbottom Institute of Agriculture, Technology and Sciences, ALLAHABAD (U.P.) INDIA (Email: shailjachaudhary0@gmail.com)
} 